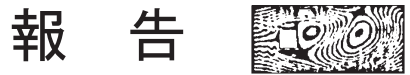

\section{第八回 日本風工学会若手スクール報告 Report of the Eighth JAWE School for Young Members}

\author{
佐々木 澄*1 長谷部 寛*2
}

Kiyoshi SASAKI, Hiroshi HASEBE

\section{1.はじめに}

平成 28 年度日本風工学会年次大会の前日である 5 月 24 日（火）に第八回日本風工学会若手スクールが実施さ れた。若手スクールは，風工学の将来を担う大学院生と 若手研究者を対象としたもので，運営・学術委員会によ つて開催されるものである。今年度の参加者は合計 22 名 （懇親会のみが 2 名）で，土木，建築，電力，鉄道など 様々な分野の研究者，実務者，学生であった。なお，学 生は 5 名でいずれも博士課程であった。過去に大学院生 として参加した経験のある方が，社会人になって再度参 加いただいたり，昨年度参加して興味を持ったことから 参加いただいた方もいたりと，継続性が見られたことは 喜ばしい一方，より若い修士課程の学生の参加がなかっ たことは残念であった。

\section{2. 若手スクールの概要と開催内容}

下記に今年度の若手スクールのプログラムを示す。今 年度は茨城県つくば市にある気象研究所と気象測器検定 試験センターを見学した。また, 懇親会を日本大学理工 学部駿河台キャンパスに移動して行った。

- 13:00-13:15 気象研究所概要紹介

- 13:20-14:10 突風観測に関する研究の紹介

・14:15-15:15 施設見学 (フェーズドアレイレーダー, 大型風洞装置)

\section{移動}

・15:30-16:30 気象測器検定試験センターの紹介及び
検定用風洞の見学

日本大学理工学部駿河台キャンパスへ移動

- 18:30-20:30 懇親会

\section{1 気象研究所}

はじめに, DVD を視聴するとともに, 気象研究所企画 室の西尾氏より気象研究所全体の説明を受けた。続いて,

「竜巻等突風の探知 -フェーズドアレイレーダーが切 り拓く世界-」という題目で，気象研究所気象衛星・観測 システム研究部の楠氏よりご講演いただいた。取り組み として，竜巻や突風等の顕著現象の監視・予測技術につ いてと，実際の竜巻の事例としてつくばで起こった竜巻 の被害調査事例の紹介があった。その後，基礎的な内容 として竜巻の生成要因・メカニズムの説明と，観測装置 であるレーダーの測定原理を説明され，実際に竜巻を捉 えた画像の紹介とともに，非常に複雑な構造であること を示された。次に実際の竜巻の観測事例として，山形県 酒田市の沿岸で，超音波風速計 12 台と気圧計 25 台を用 いた地上付近での計測の内容をご説明いただいた。この 観測では上空の渦についてはドップラーレーダーを用い ているとのことであった。ここでは，理想的な渦である ランキン渦と修正ランキン渦の間の渦が観測され，様々 な構造の渦と理想の渦との比較などを行い，渦の個別探 知や追跡に関する検討を行っている。この追跡技術につ いては，被害調査事例のある埼玉県越谷市で起こった竜 巻に適用したところ，概ね良好な結果が得られたという ことであった。現状，実用化はされていないが，様々な

\footnotetext{
* 1 清水建設株式会社技術研究所 主任研究員

Senior Research Engineer, Institute of Technology, Shimizu Corporation

* 2 日本大学理工学部 専任講師

Assistant Professor, Nihon University, College of Science and Technology
} 


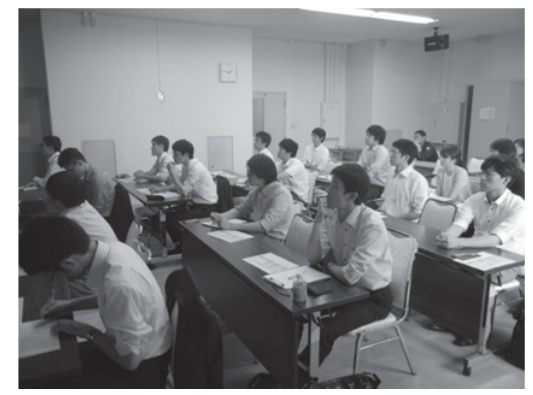

写真 1 気象研究所会議室での様子

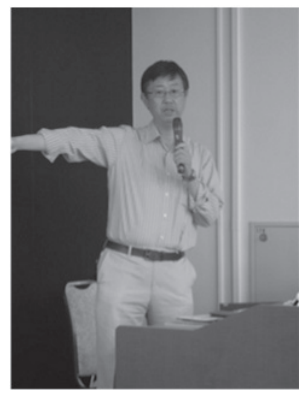

写真 2 講演される楠氏

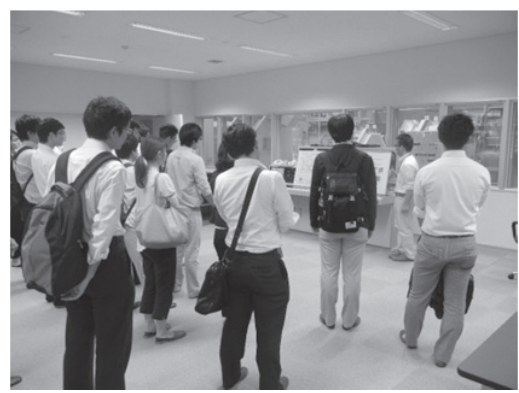

写真 3 検定用風洞見学の様子
竜巻を数分〜数十分前に追跡できるところまで技術が整 備されつつあるとのことであった。続いて, 本講演の後 に見学予定であったフェーズドアレイレーダーについて のご説明があった。はじめに，竜巻等は時間として十分 程度の現象であるため, 全貌を捉えるための高速レーダ 一の必要性について話された。従来のドップラーレーダ 一は，ある 1 仰角面の風況を捉えるものであり，全貌を 捉えるためには複数仰角面を計測する必要があるが，時 間がかかってしまう。平成 27 年度から気象研究所で運用 を開始したフェーズドアレイレーダーでは, 鉛直 1 次元 に 128 本の棒状アンテナを用い, 超高速スキャンが可能 になった。本装置では, 100 面の風況を 30 秒で計測可能 となり, 積乱雲や竜巻を捉えることができるようになり, 実際の映像の紹介があった。短時間に現象を捉え, デー 夕を取得できる一方，コス卜が高い，大容量データの処 理が必要, 山の起伏や建物の影響を受けやすい，等の欠 点を挙げられた。現状, 気象研究所敷地内にある高さ $40 \mathrm{~m}$ の鉄塔の上に設置され，つくばから $60 \mathrm{~km}$ 圈内を測定対 象としているとのことであった。竜巻の大きさや形状, 地上の観測結果とのずれの把握等とともに, 雷の放電計 測との組み合わせ，航空機ルートの選定への利用等を視 野に入れた研究を進めているとの説明があった。

講演終了後, 実際にフェーズドアレイレーダーの装置 を見学した。地上 $40 \mathrm{~m}$ の鉄塔を登り，測定概要等の説明 を受けながら装置の実物を見学した。

その後, 大型気象風洞装置を見学した。風洞では, 気 象研究所環境・応用気象研究部の毛利氏よりご説明があ り, 都市の風況や地形の影響だけではなく, 海上の風況 等，風洞を使って実施している実験の紹介を受けるとと もに，実際の測定装置・模型をご紹介いただいた。

気象研究所での講演・見学を通じて,「観測されない竜 巻がかなり多いということが印象的であった」,「あまり 馴染のないレーダー観測技術が大变興味深かった」,「1m 四方程度の大きさの装置で $60 \mathrm{~km}$ 圈内を測定しているこ
とに驚きを覚えた」,「フェーズドアレイレーダーや大型 風洞等, 普段見ることのできない施設を見学できる貴重 な機会となった」,「大型風洞内にはいくつかの都市模型 が保管されており, 気象分野と風工学の近さを感じた」, 等の感想が寄せられた。

\section{2 気象測器検定試験センター}

気象研究所の見学終了後, 同じ敷地内にある気象測器 検定試験センターへ移動し, センターのご紹介を受け, 検定用風洞を見学した。

まず, センターの概要について, 気象測器検定試験セ ンターの荻原氏よりご説明があった。センターの業務の 3 つの柱として, 1)気象測器の準器の維持と検定及び部内 検査, 2)気象測器の試験・開発（技術開発），3）世界気象 機関（WMO）第二地区（アジア）測器センター, があ るとご説明された。1)に関しては，世界的なトレーサビ リティの観点からも準器の維持を行うとともに, 部内検 査として全国の AMeDAS 等の気象測器のオーバーホー ル及び検查を実施しているとのことであった。2)につい て, 近年は気象測器の開発よりも観測所周辺環境が観測 結果に与える影響の調査に重点をおいていると述べられ た。3)については, 観測データの品質を向上・維持する ために, アジアの国々に対し気象測器の校正や技術指導 を行っており，予測技術への利用のためにも世界規模で の観測技術・精度向上を目指しているとのことであった。 続いて, 本説明の後に見学寸る検定用風洞の概要につい てのご説明があった。検定用風洞の歴史ということで, つくばに移設される前の検定用風洞の紹介もあり, 現在 のものが 3 代目であるとのことであった。気象業務法に 基づく検定を実施しており, 各種機器の器差の把握の他 にも, 計測可能な最大風速の 1.2 倍の風速における力に 耐えうるかどうか，という構造検査も行われているとの ことで, 現在の検定用風洞では, $108 \mathrm{~m} / \mathrm{s}$ まで風が吹かせ られるとのことであった。

その後, 実際に検定用風洞を見学した。風洞では, 気 
象測器検定試験センターの新垣氏より風路内の風速の測 定方法の説明や検定方法についての紹介があった。風路 の周囲をまわりながら, 検定する測定機器の設置の方法 等の説明を受け, 最後には風速 $90 \mathrm{~m} / \mathrm{s}$ の風を実際に吹か せていただいた。

気象測器検定センターの見学を通じ, 「測定精度を保つ ための種々の工夫に感銘を受けた」, 「90 m/s の風まで吹 かせていただき，音と風速計可動部の動きで体感するこ とができ，貴重な体験ができた」，等の感想があった。

\section{3 懇親会}

見学会終了後, 日本大学理工学部駿河台キャンパスー 移動し, 業務の関係上, 見学会には参加できなかった方 も合流し, 懇親会を行った。例年通り, 参加者の皆様に はご自身の研究・実務内容の紹介を含めた自己紹介をお 願いした。会全体を通じて, 何度か参加されている方も いらっしゃったため, 良い雰囲気で交流を深めた。

\section{3.おおりに}

今年度の若手スクールも, 例年と同程度の参加者が集 まり, 分野も多岐に渡る等, 一つの企画として充実して いる感は得られた。参加者からは,「他の若手の方々がじ ういったものに興味を持って研究に取り組んでいるか聞 いて刺激を受けた」，「普段は異なる分野で活動している 人達が，一堂に会して話をできるという点に若手スクー ルの最大の意義があると思う。特に年齢の近い方々が集 まり, 風工学という学問や, 風工学会自体の将来につい て語り合うことに大きな価值を感じる」,「これからは, 年 1 回のスクールだけではなく, 若手の研究会等が開催 されるようになれば」, といった感想が寄せられた。

今後も若手スクールのような貴重な場を継続すること は重要であると考えられる。参加者については, 風工学 の裾野を広げる観点からも, 特に学生の参加者が増える ことを期待する。“はじめに”でも触れたが，今年度は修

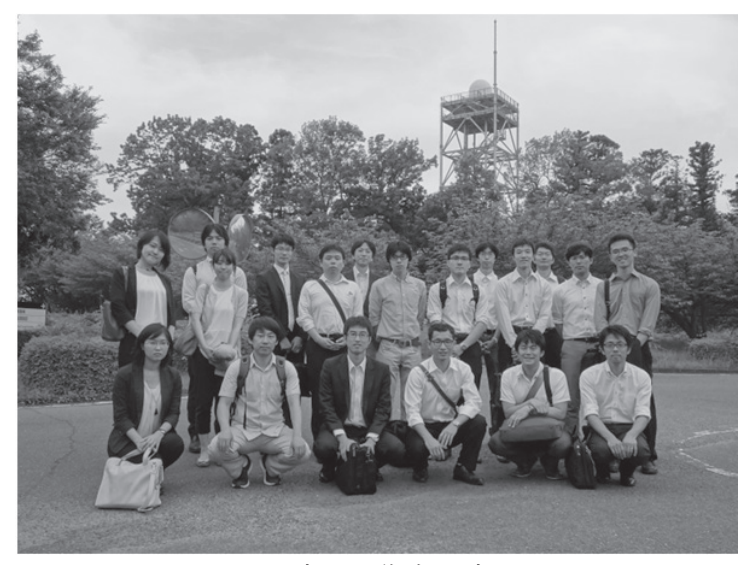

写真 4 集合写真

(後方がフェーズドアレイレーダー)

士課程の大学院生の参加者がいなかった点はとても残念 である。より多くの方が参加しやすい環境作り, 多くの 方が興味を持つ企画の提案, について検討していく必要 があると考えられる。第 1 回から参加しているような常 連の方々の年齢も上がっている中, 今後も若手のネット ワークを充実させるためにも, 参加者の方々はもちろん のこと, 学会員の皆样には身近な関係者に若手スクール の良さをお伝えいただき, 輪を広げるためにお力をお貸 しいただきたいと思う。

謝辞

第八回若手スクールを開催するにあたり、見学会の実 施にご尽力いただいた気象庁気象研究所企画室 西尾友 利様, 気象庁観測部観測課気象測器検定試験センター 荻原裕之様をはじめとする, 気象研究所, 気象測器検定 試験センターの皆様に厚く御礼を申し上げます。最後に, 若手スクールの実施を支援していただいた日本風工学会 の皆様に深く感謝申し上げます。 